\title{
Correction to: Chronic toxicity of low dose monosodium glutamate in albino Wistar rats
}

Josiah Okwudili Nnadozie', Udunma Olive Chijioke², Okechukwu Charles Okafor ${ }^{3}$, Daniel Bankole Olusina ${ }^{3}$, Angus Nnamdi Oli ${ }^{4}$, Patience Chiebonam Nwonu ${ }^{5}$, Herbert Orji Mbagwu ${ }^{6}$ and Chioli Pascal Chijioke ${ }^{7 *}$ (D)

\section{Correction to: BMC Res Notes (2019) 12:593} https://doi.org/10.1186/s13104-019-4611-7

The original article [1] mistakenly omits mention of grant funding which partially funded the work undertaken in this article. The authors sincerely apologise for this omission and would like to acknowledge this funding source in this correction article as per the below information:

1. TETFund (Tertiary Education Trust Fund): Institution based TETFund grant. [TETFUND/DESS/UNI/ NSUKKA/2017/RP/VOL.I].

\begin{abstract}
Author details
${ }^{1}$ Department of Chemical Pathology, Nnamdi Azikiwe University Teaching Hospital, Nnewi, Nigeria. ${ }^{2}$ Department of Medical Laboratory Sciences, College of Medicine, University of Nigeria Enugu Campus, Enugu, Nigeria. ${ }^{3}$ Department of Morbid Anatomy, College of Medicine, University of Nigeria Enugu Campus, Enugu, Nigeria. ${ }^{4}$ Department of Pharmaceutical Microbiology and Biotechnology, Faculty of Pharmaceutical Sciences, Nnamdi Azikiwe University, Agulu, Anambra State, Nigeria. ${ }^{5}$ Department of Pharmacology \& Toxicology, Faculty of Pharmaceutical Sciences, University of Nigeria, Nsukka, Enugu State, Nigeria. ${ }^{6}$ Department of Pharmacology \& Toxicology, College of Medicine, University of Uyo, Uyo, Akwa Ibom State, Nigeria. ${ }^{7}$ Department of Pharmacology and Therapeutics, College of Medicine, University of Nigeria Enugu Campus, Enugu, Nigeria.
\end{abstract}

Published online: 09 January 2020

\author{
Reference \\ 1. Nnadozie JO, Chijioke UO, Okafor OC, Olusina DB, Oli AN, Nwonu PC, \\ Mbagwu HO, Chijioke CP. Chronic toxicity of low dose monosodium \\ glutamate in albino Wistar rats. BMC Res Notes. 2019;12:593. https://doi. \\ org/10.1186/s13104-019-4611-7.
}

\section{Publisher's Note}

Springer Nature remains neutral with regard to jurisdictional claims in published maps and institutional affiliations. adaptation, distribution and reproduction in any medium or format, as long as you give appropriate credit to the original author(s) and the source, provide a link to the Creative Commons licence, and indicate if changes were made. The images or other third party material in this article are included in the article's Creative Commons licence, unless indicated otherwise in a credit line to the material. If material is not included in the article's Creative Commons licence and your intended use is not permitted by statutory regulation or exceeds the permitted use, you will need to obtain permission directly from the copyright holder. To view a copy of this licence, visit http://creativecommons.org/licenses/by/4.0/. The Creative Commons Public Domain Dedication waiver (http://creativecommons.org/publicdomain/zero/1.0/) applies to the data made available in this article, unless otherwise stated in a credit line to the data. 